\title{
Expression of estrogen receptor beta in the breast carcinoma of BRCAI mutation carriers
}

\author{
Maria M Litwiniuk*1, Krzysztof Rożnowski ${ }^{1}$, Violetta Filas ${ }^{1}$, \\ Dariusz D Godlewski ${ }^{2}$, Małgorzata Stawicka ${ }^{2}$, Remigiusz Kaleta ${ }^{3}$ and \\ Jan Bręborowicz ${ }^{1}$
}

\begin{abstract}
Address: ${ }^{1}$ Clinic of Oncology, Poznan University of Medical Sciences, Poznan, Poland, 2 Prophylactics and Epidemiology Centre in Poznan, Poznan, Poland and ${ }^{3}$ Private Oncological Practice, Gliwice, Poland

Email: Maria M Litwiniuk* - litwiniuk@skrzynka.pl; Krzysztof Rożnowski - krzysztof.roznowski@oncology.am.poznan.pl; Violetta Filas - vfilas@wp.pl; Dariusz D Godlewski - godlewski.open@wp.pl; Małgorzata Stawicka - gosiastawicka.open@wp.pl; Remigiusz Kaleta - remigiusz.kaleta@pharmacia.com; Jan Bręborowicz - janbreborowicz@wp.pl

* Corresponding author
\end{abstract}

Published: 13 April 2008

BMC Cancer 2008, 8:100 doi:10.1 |86/147|-2407-8-100
Received: 5 November 2007

Accepted: 13 April 2008

This article is available from: http://www.biomedcentral.com/I47I-2407/8/100

(c) 2008 Litwiniuk et al; licensee BioMed Central Ltd.

This is an Open Access article distributed under the terms of the Creative Commons Attribution License (http://creativecommons.org/licenses/by/2.0), which permits unrestricted use, distribution, and reproduction in any medium, provided the original work is properly cited.

\begin{abstract}
Background: Breast cancers $(B C)$ in women carrying mutations in BRCAI gene are more frequently estrogen receptor negative than the nonhereditary BC. Nevertheless, tamoxifen has been found to have a protective effect in preventing contralateral tumors in BRCAI mutation carriers. The identification of the second human estrogen receptor, $E R \beta$, raised a question of its role in hereditary breast cancer. The aim of this study was to assess the frequency of ER $\alpha$, ER $\beta$, $\mathrm{PgR}$ (progesterone receptor) and HER-2 expression in breast cancer patients with mutated BRCAI gene and in the control group.

Methods: The study group consisted of 48 women with BRCAl gene mutations confirmed by multiplex PCR assay. The patients were tested for three most common mutations of BRCAI affecting the Polish population (5382insC, C6IG, 4I53delA). Immunostaining for $E R \alpha, E R \beta$ and $P g R$ (progesterone receptor) was performed using monoclonal antibodies against ER $\alpha, \operatorname{PgR}$ (DakoCytomation), and polyclonal antibody against ER $\beta$ (Chemicon). The EnVision detection system was applied. The study population comprised a control group of 120 BC operated successively during the years 1998-99.

Results: The results of our investigation showed that BRCAI mutation carriers were more likely to have $E R \alpha$-negative breast cancer than those in the control group. Only $14.5 \%$ of $B R C A I$-related cancers were ER $\alpha$-positive compared with $57.5 \%$ in the control group $(P<0.000 I)$. On the contrary, the expression of ER $\beta$ protein was observed in $42 \%$ of BRCA I-related tumors and in $55 \%$ of the control group. An interesting finding was that most hereditary cancers $(75 \%$ of the whole group) were triple-negative: $\operatorname{ER} \alpha(-) / \mathrm{PgR}(-) / \mathrm{HER}-2(-)$ but almost half of this group (44.4\%) showed the expression of ER $\beta$.

Conclusion: In the case of $B R C A$ I-associated tumors the expression of $\operatorname{ER} \beta$ was significantly higher than the expression of ER $\alpha$. This may explain the effectiveness of tamoxifen in preventing contralateral breast cancer development in BRCAI mutation carriers.
\end{abstract}




\section{Background}

In 1990 Hall et al. discovered that familial breast cancer is associated with a defect in one of the genes located in the 17 q21 chromosome [1]. This finding began a new era of research into hereditary breast cancer and consequently led to the identification of the BRCA1 and BRCA2 suppressor genes in 1994 and 1995, respectively. Although the structures and localization of the BRCA1 and BRCA2 genes differ, their functions seem to be similar because their transcripts are involved in the same processes [2-6]. These genes are responsible for maintaining the proper course of the cell cycle, for the repair of DNA damage, and are also instrumental in the process of cell differentiation. BRCA1 is also partially responsible for the activity of estrogen receptors (ER) and, when mutated, can inhibit the functions of these receptors [7].

BRCA1 and BRCA2 gene mutation carriers are at risk of developing breast cancer earlier than other patients. Breast cancer associated with this mutation has characteristic histopathological features: (i) the expression of estrogen and progesterone receptors is less frequently demonstrable, (ii) the grade of histopathological malignancy is higher and (iii) accumulation of p53 protein is observed more often than in sporadic cases of this malignancy $[8,9]$. Although these factors are usually associated with a poorer prognosis, their role in BRCA1 and BRCA2 mutation carriers is still controversial [10-15].

The role of tamoxifen in preventing the development of contralateral breast cancer in BRCA1 mutation carriers is not fully understood since it significantly reduces that risk despite low expression of ER [16]. The mechanism responsible for that has not been yet explained and estrogen receptor $\beta$ may play a role here.

Estrogen receptor $\beta$ (ER $\beta)$ was discovered in 1996 and was given its name in order to differentiate it from the previously known type of estrogen receptor (now named estrogen receptor $\alpha-\mathrm{ER} \alpha)[17,18]$. The two estrogen receptors belong to a family of ligand-regulated transcription factors. They are transcripts of different genes sharing some structural similarities. When co-expressed, ER $\alpha$ and ER $\beta$ may form homo- or heterodimers upon binding specific ligands. As dimers, ERs are able to start transcription activity in two ways: through direct binding to specific regions of DNA, or through protein-protein interaction with other transcription factors. In the case of co-expression of both ERs, their roles may overlap. In certain situations, however, ER $\beta$ opposes the activity of ER $\alpha$ via the inhibition of ER $\alpha$-mediated gene expression. These differences are also observed in the response to tamoxifen. This selective estrogen receptor modulator may work as a pure ER antagonist for ER $\beta$, while it may have a partially agonistic effect for ER $\alpha$ [19]. In spite of increasing knowledge regarding the structure and in vitro activity of ER $\alpha$ and ER $\beta$, their clinical role is still controversial and unclear [20].

For a better understanding of the functions of ER $\beta$ we explored its expression in BRCA1 mutation carriers and looked for coexistence patterns with other hormonal receptors $(\mathrm{ER} \alpha, \mathrm{PgR})$ and HER-2 receptor.

\section{Methods}

The study group included 48 patients with mutations in the BRCA1 gene. The control group consisted of 120 subsequent breast cancer cases diagnosed over the period of 1998-1999. Patients from both groups underwent breast surgery from which specimens for histological and immunohistochemical testing were obtained. The study was approved by the local Bioethics Committee at the Medical University in Poznań.

Results of genetic tests were obtained from the Prophylactics and Epidemiology Center in Poznań. In the search for mutations in the BRCA1 gene, tests were performed on DNA isolated from peripheral blood lymphocytes using a commercially available kit. They were carried out for three most common mutations of BRCA1 gene affecting the Polish population (5382insC, C61G, 4153delA). In Poland those three mutations in BRCA1 account for $86 \%$ of all BRCA1 and BRCA2 mutations. In the search for 5382insC and 4153delA mutations, the ASA-PCR method was used. For the detection of C61G mutation, the RELPPCR method was applied.

Histological and immunohistochemical tests were completed in the Department of Tumor Pathology of the Medical University in Poznań. From formalin fixed and paraffin embedded specimens, $4 \mu \mathrm{m}$ sections were cut and mounted onto positively charged glass microscope slides (Superfrost Plus, Menzel-Glaser, Germany). The sections were deparaffinized, rehydrated and subjected to antigen retrieval in citrate buffer in a microwave oven. The slides were then incubated in 3\% hydrogen peroxide for $10 \mathrm{~min}$ utes to block endogenous peroxidase activity.

The primary antibodies used for immunostaining were as follows:

1. for ER $\alpha$ - a monoclonal mouse antibody clone 1D5 (Dako, Glostrup, Denmark; code No M 7047) was used at 1:50 dilution and slides were incubated at room temperature for $1 \mathrm{~h}$;

2. for ER $\beta$ - a polyclonal rabbit antibody in which immunogen corresponds to NH2-terminus of the human ER $\beta$, and, according to the manufacturer, the sequence used is conserved in all known isoforms (Chemicon International, Temecula, CA; catalog No AB1410). This antibody 
Table I: Clinicopathological characteristics of patient cohorts

\begin{tabular}{|c|c|c|c|}
\hline Parameter & BRCAI-associated breast cancers $n=48$ & Control group $n=120$ & $P$-value \\
\hline \multicolumn{4}{|l|}{ Age } \\
\hline median (range) & $45(29-68)$ & $57(38-85)$ & $<0.0001$ \\
\hline Age $>50$ years & $16(33 \%)$ & $82(68 \%)$ & \\
\hline \multicolumn{4}{|l|}{ Histological type } \\
\hline invasive ductal & $42(87 \%)$ & $103(85.8 \%)$ & 0.7993 \\
\hline invasive lobular & I $(2 \%)$ & $10(8.3 \%)$ & 0.14 \\
\hline medullary like & $5(10 \%)$ & 0 & $<0.001$ \\
\hline other & 0 & $9(7.5 \%)$ & $<0.001$ \\
\hline \multicolumn{4}{|l|}{ Tumor grade } \\
\hline 1 & $\mathrm{I}(2.0 \%)$ & $36(29 \%)$ & $<0.001$ \\
\hline II & II (22.9\%) & $53(44.1 \%)$ & 0.0122 \\
\hline III & $27(56.2 \%)$ & $26(21.7 \%)$ & $<0.0001$ \\
\hline unknown & $9(18.7 \%)$ & $5(4.2 \%)$ & 0.0017 \\
\hline \multicolumn{4}{|l|}{ Tumor size } \\
\hline median & 2.2 & 3.0 & 0.14 \\
\hline$\leq 2 \mathrm{~cm}$ & $28(58.3 \%)$ & $53(44.1 \%)$ & 0.102 \\
\hline$>2 \mathrm{~cm} \leq 5 \mathrm{~cm}$ & $16(33.3 \%)$ & $50(4 \mid .6 \%)$ & 0.282 \\
\hline$>5 \mathrm{~cm}$ & $3(6.2 \%)$ & $17(14.1 \%)$ & 0.147 \\
\hline unknown & $\mathrm{I}(2.0 \%)$ & 0 & \\
\hline \multicolumn{4}{|l|}{ Lymph node } \\
\hline negative & 34 (70.8\%) & $52(43.3 \%)$ & 0.001 \\
\hline positive $\leq 3$ & $8(16.6 \%)$ & $38(31.6 \%)$ & 0.015 \\
\hline positive $>3$ & $4(8.3 \%)$ & $22(18.0 \%)$ & 0.104 \\
\hline unknown & $2(4.1 \%)$ & $8(6.6 \%)$ & \\
\hline Bilateral breast cancer & 13 (27.1\%) & $2(1.7 \%)$ & $<0.0001$ \\
\hline \multicolumn{4}{|l|}{ Mutation: } \\
\hline 5382ins $C$ & 37 (77.5\%) & & \\
\hline C6IG & $10(20.4 \%)$ & & \\
\hline 4153 delA & I $(2 \%)$ & & \\
\hline
\end{tabular}

was used at dilution of 1:500 and overnight in an incubation chamber at $4^{\circ} \mathrm{C}$;

3. for PgR - a monoclonal mouse antibody clone PgR636, (Dako, Glostrup, Denmark; code M 3569) was used at a dilution of 1:100 and slides were incubated at room temperature for $1 \mathrm{~h}$. This antibody (according to the manufacturer) has been demonstrated by Western blot to react with both forms of the progesterone receptor: the PR-A and PR-B.

The antibody reactions were revealed using Dako EnVision $^{\mathrm{TM}}+$ System-HRP. Subsequently the slides were incubated in DAB chromogen for 5 minutes at room temperature. The sections were counterstained with hematoxylin, and coverslipped.

Immunostained slides were evaluated by two independent observers in a "blinded" fashion, using light micros- copy. Tumors were considered to be expressing receptors if a positive reaction (regardless of its intensity) was identified in at least $10 \%$ of the cancer cells' nuclei.

HER-2 protein was identified by means of the HecepTest ${ }^{\mathrm{TM}}$ kit (Dako). Tumors were classified as $0,1+, 2+$ or $3+$ on the basis of the spread and intensity of membranous staining in invasive portions of the cancer. Tumors showing staining reactions in class $3+$ were considered to be over-expressing HER-2. In the case of the $2+$ results obtained, suggestive of over-expression of the HER-2 protein, amplification of the c-erbB2 gene was tested by the application of fluorescent in-situ hybridization (FISH). Cases with an immunohistochemistry result of $2+$ but without amplification of the gene, as tested by FISH, were not considered to be over-expressing HER2.

To assess dependences Fisher' Exact Test (for $2 \times 2$ contingency tables) and the Fisher-Freeman-Halton (for larger 
contingency tables) test were applied. Significance was accepted at $P<0.05$.

\section{Results}

The clinicopathological characteristics of breast cancer patients with mutated BRCA1 gene and those of the control group are shown in Table 1. BRCA1 gene mutations in the study group were identified as follows: 5382insC (77.5\%), C61G (20.4\%) and 4153delA (2\%).

The average age of patients with mutations in the BRCA1gene was 45 years, and 57 years in the control group.

Invasive ductal carcinoma (no special type) was found to occur at the same frequency in both the BRCA1-positive group as well as the control group (87\% and $85.8 \%$, respectively). Other tumor types were much less frequent, although it is noteworthy that all 5 patients with "medullary like" carcinoma came from the BRCA1 mutation carriers group (10\%).

The assessment of histological malignancy was performed according to the Bloom-Richardson classification and showed that patients carrying BRCA1 mutations developed grade 3 tumors more often and had less frequent metastases to axillary lymph nodes.

In the BRCA1-positive group, the rate of patients who developed bilateral breast cancer accounted for $27.1 \%$ (13 cases). In the control group, bilateral breast cancer was found in 2 patients only $(1.7 \%)$.

The presence of estrogen receptor $\alpha$ was detected in the tumors of 7 (14.5\%) patients with BRCA1gene mutations and in 69 patients (57.5\%) in the control group (Fig. 1).

For progesterone receptors, the figures were $6(12.5 \%)$ and $77(64 \%)$, respectively. The expression of estrogen receptor $\beta$ was detected in the tumors of $20(42 \%)$ of the BRCA1-mutation patients and in 66 (55\%) of the subjects in the control group (Table 2) (Fig. 2).

In the group with BRCA1 mutations, the most frequently found phenotype was $\operatorname{ER} \alpha(-) / \operatorname{ER} \beta(-)$ observed in $52 \%$ of

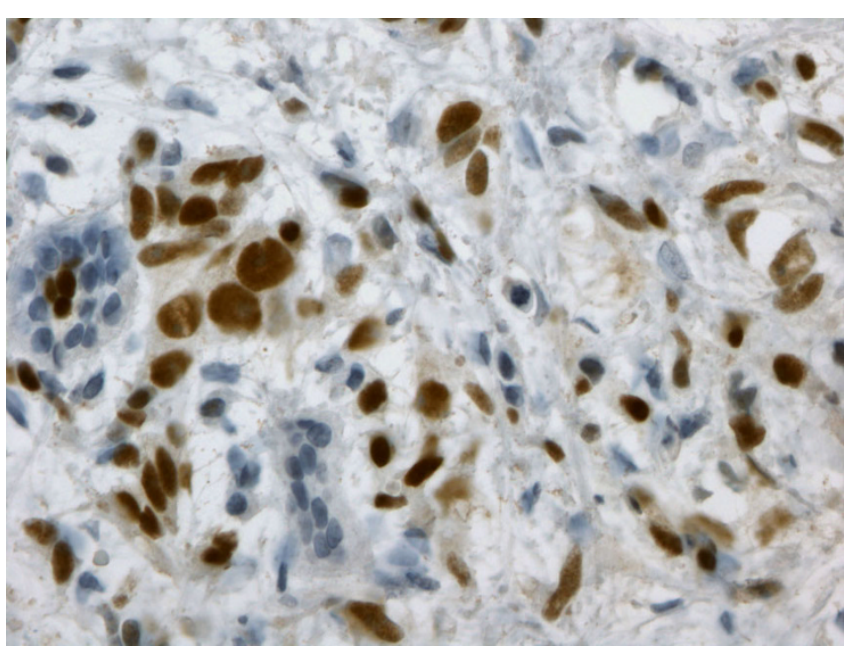

\section{Figure I}

$E R \alpha$ immunostaining on paraffin-embedded invasive breast cancer using ID5 Dako antibody (40x magnification).

patients, followed by $\operatorname{ER} \alpha(-) / \operatorname{ER} \beta(+)$ noticed in $33.3 \%$ cases. In the control group only $14.2 \%$ of the patients presented phenotype $\operatorname{ER} \alpha(-) / \operatorname{ER} \beta(+)$. The most common phenotype observed in that group was $\operatorname{ER} \alpha(+) / \operatorname{ER} \beta(+)-$ 40.8\% (Table 3).

The over-expression of the HER-2 receptor in patients with mutated BRCA1 genes was observed only in 3 cases $(6.2 \%)$. In the control group over-expression of HER-2 was found in 20 cases $(16.7 \%)$.

An interesting finding of this study is that most hereditary cancers have been found to be triple-negative: $\operatorname{ER} \alpha(-) /$ $\operatorname{PgR}(-) /$ HER-2(-). Such a phenotype was found in 36 cases, which accounts for $75 \%$ of the whole group of patients with a mutated BRCA1 gene. 16 patients in that group expressed ER $\beta$ and presented the following phenotype: $\operatorname{ER} \alpha(-) / \operatorname{PgR}(-) / \operatorname{HER} 2(-) / \operatorname{ER} \beta(+)$. In the control group, the triple-negative phenotype was found in 24 patients $(20 \%)$ of whom 5 had tumors expressing ER $\beta$.

\section{Discussion}

In our study, patients with BRCA1 gene mutations were tested for the expression of steroid receptors (ER $\beta, \mathrm{ER} \alpha$

Table 2: Receptor status in BRCAI-associated breast cancer and in cancer of the control group

\begin{tabular}{lcccc}
\hline Expression of steroid receptors & $\begin{array}{c}\text { BRCA I-associated breast cancers } n=48 \\
(\%)\end{array}$ & $\begin{array}{c}\text { Control group } n=120 \\
n\end{array}$ & $\begin{array}{c}P \text {-value } \\
(\%)\end{array}$ \\
\hline $\operatorname{ER} \alpha(+)$ & 7 & 14.5 & 69 & 57.5 \\
$\operatorname{ER} \beta(+)$ & 20 & 42 & 66 & 55 \\
$\operatorname{PgR}(+)$ & 6 & 12.5 & 77 & 0.0001 \\
$\operatorname{HER} 2(+)$ & 3 & 6.2 & 20 & 64 \\
\hline
\end{tabular}




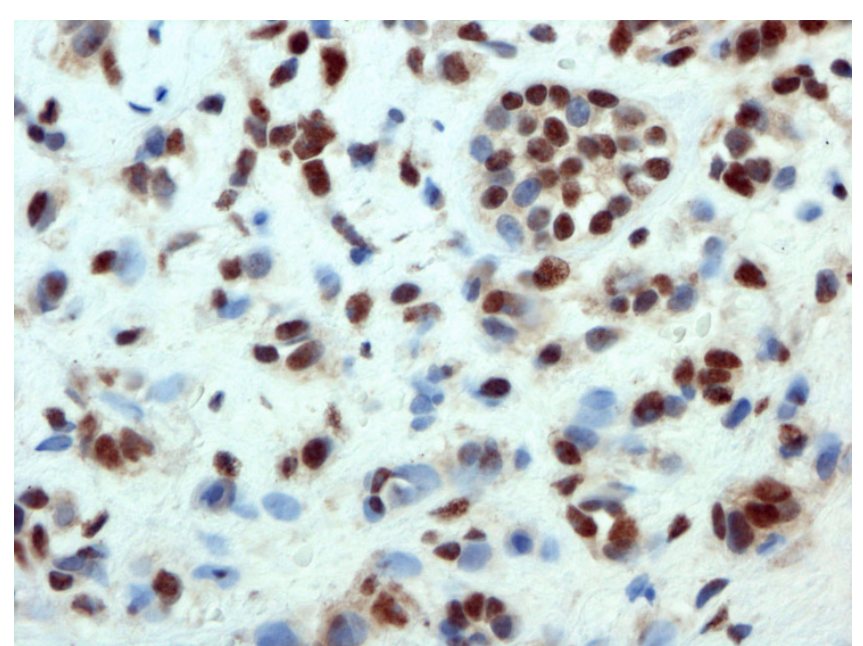

Figure 2

$E R \beta$ immunostaining on paraffin-embedded invasive breast cancer using antibody from Chemicon (40x magnification).

and PgR) and the HER-2 receptor in breast cancer tissue. In this group, ER $\beta$ was more common (42\%), while ER $\alpha$ and PgR occurred less frequently $(14.5 \%$ and $12.5 \%$ respectively). In the control group, the expression of ER $\alpha$ and PgR was 57.5 and 64\%, respectively. In the case of $\mathrm{ER} \alpha$ and PgR, the differences between the two groups were found to be statistically significant $(\mathrm{p}=0.001)$. Those values are similar to those described by other authors $[8,12,21,22]$. In the case of ER $\beta$, however, the differences of expression between those two groups were small.

Most of our control group patients were tested for the presence of BRCA1 mutations. Although those tests were not performed on all the controls, this cannot influence the overall findings of the study since in Poland BRCA1 mutations (unselected for age) occur only in about 3\% of all breast cancer patients [23].

It has been pointed out in many studies that BRCA1 positive breast cancers rarely express ER $\alpha$ [8-12,20,21]. Further confirmation of that observation comes from recent studies made with the use of the cDNA microarray technique, showing that breast cancers may vary considerably in their molecular profile [24,25]. The largest group consists of tumors with a cellular profile matching that of the inner layers of the mammary glands, such as luminal cells (luminal types) and another group consists of tumors with basal cell profiles (basal types). These two groups differ in their expression of ER $\alpha$. The luminal types express $\mathrm{ER} \alpha$, while the basal types usually do not. cDNA studies of breast cancers with underlying BRCA1 gene mutations show that the most common cancer type in this group is basal [26]. Moreover, basal type tumors show expression of receptors for epidermal growth factor (EGFR) more often. Generally, about half of the patients with BRCA1 gene mutations present the phenotype ER(-)/HER2(-)/ $\operatorname{EGFR}(+)$ of the basal type of tumor, which is usually associated with poor prognosis [26-28]. On the other hand, there are data that suggest that the prognosis for BRCA1positive patients is no worse than that for patients without mutations [10-14]. This discrepancy may suggest the influence of some incompletely explored prognostic and predictive factor(s).

Recent analyses suggest that ER $\beta$ may be an independent prognostic and predictive factor in the course of breast cancer [29-33]. However, its role has not yet been fully discovered. It is noteworthy that in our clinical material (in contrast to ER $\alpha$ ) the expression of the ER $\beta$ in tumor tissues of patients with BRCA1 gene mutations is almost as frequent as in the non-hereditary breast cancer patients. It would be interesting to test whether frequent representation of ER $\beta$ in BRCA-positive tumors is actually responsible for the earlier reported activity of tamoxifen in the reduction of contralateral breast cancer risk.

Fan et al. showed that there is a link between estrogen receptors and the BRCA1 protein. In an in vitro study, BRCA1 protein proved to be one of the transcription regulators for active ER $\alpha$. The transcription co-activator p300 plays an important role in this process, and its presence correlates with the ability of the BRCA1 protein to suppress the activation of ER $\alpha$ transcription [7].

Our study group displayed certain characteristics of hereditary breast cancer. One of these features was the young age of the patients. In this group, the average age of breast cancer diagnosis was 45 years, 12 years earlier than in the control group. The same average age at which the diagnosis was established, was reported for Spanish families and a similar age (43 years) in Markus's study of the population of Ashkenazi Jews [10]. Age is a well known factor influencing the expression of ER $\alpha$. The fact that there was a 12-year difference in the average age between the BRCA1 gene mutations group and the control group must have some influence on the reported ER $\alpha$ expression in our study. Regarding ER $\beta$ expression, however, we believe that difference bears no material significance on the result. Our opinion is based on the fact that numerous studies have indicated that the expression of ER $\beta$ is not agedependent.

In both groups, the most frequent histological diagnosis was that of ductal carcinoma $(87 \%$ and $85.8 \%$, respectively). Another common histological type of breast cancer found in the mutation carriers group was "medullary like" carcinoma (10\%). In the control group, however, not a single case of that type of cancer was identified. A higher rate of "medullary like" carcinoma is typical of 
Table 3: The distribution of ER $\alpha$ and ER $\beta$ in BRCAI-associated breast cancers and in cancers of the control group

\begin{tabular}{|c|c|c|c|c|c|}
\hline \multirow[t]{2}{*}{ Receptors' status } & \multicolumn{2}{|c|}{ BRCAI-associated breast cancers $n=48$} & \multicolumn{2}{|c|}{ Control group $n=120$} & \multirow[t]{2}{*}{$P$} \\
\hline & $\mathrm{N}$ & $(\%)$ & $\mathrm{N}$ & $(\%)$ & \\
\hline $\operatorname{ER} \alpha(+) / E R \beta(+)$ & 4 & 8.3 & 49 & 40.8 & $<0.0001$ \\
\hline $\operatorname{ER} \alpha(+) / \operatorname{ER} \beta(-)$ & 3 & 6.2 & 20 & 16.7 & 0.086 \\
\hline $\operatorname{ER} \alpha(-) / \operatorname{ER} \beta(+)$ & 16 & 33.3 & 17 & 14.2 & 0.009 \\
\hline $\operatorname{ER} \alpha(-) / \operatorname{ER} \beta(-)$ & 25 & 52 & 34 & 28.3 & 0.004 \\
\hline
\end{tabular}

BRCA1 mutation carriers and this diagnosis is associated with a relatively good prognosis $[34,35]$. Consequently, it was believed that this diagnosis positively affected the prognosis for BRCA1-positive patients. Unfortunately, a recent study failed to confirm that finding [36].

Patients with hereditary disease have been found to develop bilateral breast cancer more often. Our study has confirmed this observation as it has been found that bilateral breast cancer affected 13 patients of the study group (27.1\%).

The above characteristics of hereditary breast cancer have been frequently described in the literature and are consistent with the previously published data. Little, however, has been said regarding the expression of ER $\beta$. This appears to have been mentioned only once in a letter to the Editor of the Journal of Clinical Oncology which reported on estrogen receptor-beta expression in hereditary breast cancer where positive staining for ER $\beta$ was detectable in $94 \%$ (15 of 16) of BRCA1 associated breast cancers [37].

In our study, ER $\beta$ expression was present in $42 \%$ of BRCA1 mutation carriers. This seems to be important as it may explain the protective effect of tamoxifen in the prevention of contralateral tumor development in BRCA1 mutation carriers.

Out of the hereditary cancer patients in our study group, $75 \%$ were found to be triple-negative, lacking ER $\alpha, \mathrm{PgR}$ and HER-2 over-expression. Unfortunately, at the current state of the art, neither hormonal therapy, nor immunotherapy (trastuzumab) in an adjuvant setting, can be offered to those patients.

Gruvberger-Saal et al [38] reported that the expression of $\mathrm{ER} \beta$ is an independent marker for favourable prognosis after adjuvant tamoxifen treatment in ER $\alpha$ negative breast cancer patients. Bearing in mind that as many as $44 \%$ of the triple-negative patients in our study expressed ER $\beta$, we propose that hormone therapy might be used in the treatment of BRCA1 mutation carriers expressing the ER $\alpha(-) /$ PgR(-/HER2(-)/ER $\beta(+)$ phenotype.
The results obtained in our study show that the expression of ER $\beta$ in BRCA1 gene mutation carriers is statistically higher than the expression of ER $\alpha$. This may be why tamoxifen has proven to be effective in preventing the development of contralateral breast cancer in BRCA1 mutation carriers. Consequently, testing patients carrying BRCA1 mutations for the presence of ER $\beta$ might help to identify those who could benefit from endocrine therapy.

\section{Conclusion}

In the case of BRCA1-associated tumors the expression of ER $\beta$ was significantly higher than the expression of ER $\alpha$. This may explain the effectiveness of tamoxifen in preventing contralateral breast cancer development in BRCA1 mutation carriers.

\section{Abbreviations}

ER - estrogen receptor

ER $\alpha$ - estrogen receptor alpha

ER $\beta$ - estrogen receptor beta

PgR - progesterone receptor

BRCA1 - breast cancer associated gene

BRCA2 - breast cancer associated gene

PCR - polymerase chain reaction

HER-2 - human epidermal growth factor receptor-2

SERM - selective estrogen receptor modulator

IHC - immunohistochemistry

ASA-PCR - amplicon sequence analysis - polymerase chain reaction

RFLP-PCR - restriction fragment length polymorphism polymerase chain reaction

FISH - fluorescent hybridization in situ 
EGFR - epidermal growth factor receptor

cDNA - complementary DNA

\section{Competing interests}

The author(s) declare that they have no competing interests.

\section{Authors' contributions}

ML conceived, designed and performed the study, coordinated the work and drafted the manuscript, KR participated in the draft of the manuscript, VF performed IHC tests, DG and MS carried out genetic tests, RK reviewed the manuscript and offered some comments, JB interpreted histopathological and IHC test results. All authors have read and approved the final manuscript.

\section{References}

I. Hall JM, Lee MK, Newman B, Morrow JE, Anderson LA, Huey B, King MC: Linkage of early-onset familial breast cancer to chromosome 17q2I. Science 1990, 250:1684-I689.

2. Krainer M, Silvia-Arrieta S, Fitzgerald MG, Shimada A, Ishioka C, Kanamaru R, MacDonald DJ, Unsal H, Finkelstein DM, Bowcock A, Isselbacher KJ, Haber DA: Differential contributions of BRCAI and BRCA2 to early-onset breast cancer. N Engl J Med 1997, 336: $|4| 6-|42|$

3. Struewing JP, Hartge P, Wacholder S, Baker SM, Berlin M, McAdams M, Timmerman MM, Brody LC, Tucker MA: The risk of cancer associated with specific mutations of BRCAI and BRCA2 among Ashkenazi Jews. N Engl J Med I997, 336: I 40 I-I 408.

4. Miki Y, Swensen J, Shattuck-Eidens D, Futreal PA, Harshman K, Tavtigian S, Liu Q, Cochran C, Bennett LM, Ding W: A strong candidate for the breast and ovarian cancer susceptibility gene BRCAI. Science 1994, 266:66-7|.

5. Wooster R, Bignell G, Lancaster J, Swift S, Seal S, Mangion J, Collins N, Gregory S, Gumbs C, Micklem G, Berfoot R, Hamoudi R, Patel S, Rices C, Biggs P, Hashim J, Smith A, Connor F, Arason A, Gudmundsson J, Ficenec D, Kelsell D, Fordtonin DP, Bishop TD, Spurr NK, Ponder BAJ, Eeles R, Peto J, Devilee P, Cornelisse C, Lynch H, Narod S, Lenoir G, egilsson V, barkadottir RB, Easton DF, Bentley DR, Futreal A, Ashworth A, Stratton MR: Identification of the breast cancer susceptibility gene BRCA2. Nature 1995, 378:789-792.

6. Martin AM, Weber BL: Genetic and hormonal risk factor in breast cancer. I Natl Cancer Inst 2000, 92: I |26-35.

7. Fan S, Ma YX, Wang C, Yuan R-Q, Meng Q, Wang L-A, Erdos M, Goldberg ID, Webb P, Kushner PJ, Pestell RG, Rosen EM: p300 Modulates the BRCAI inhibition of estrogen receptor activity. Cancer Res 2002, 62:|4|-|5|.

8. Lakhani SR, van de Vijver MJ, Jacquemier J, Thomas J, Anderson TJ Osin PP, McGuffog L, Easton DF: The pathology of familial breast cancer: predictive value of immunohistochemical markers estrogen receptor, progesterone receptor, HER-2, and p53 in patients with mutations in BRCAI and BRCA2. J Clin Oncol 2002, 20:2310-2318

9. Honrado E, Benitez J, Palacios J: The pathology of hereditary breast cancer. Hereditary Cancer Clin Pract 2004, 2: I3 I-138.

10. Marcus JN, Watson P, Page DL, Narod SA, Lenoir GM, Tonin P, Linder-Stephenson L, Salerno G, Conway TA, Lynch HT: Hereditary breast cancer. Pathology, prognosis, and BRCAI and BRCA2 gene linkage. Cancer 1996, 77:697-709.

II. Porter DE, Cohen BB, Wallace MR, Smyth E, Chetty U, Dixon JM, Steel CM, Carter DC: Breast cancer incidence, penetrance and survival in probable carriers of $B R C A I$ gene mutation in families linked to BRCA I on chromosome I 7q I 2-2 I. Br J Surg I994, I0:1512-1515.

12. Verhoog LC, Brekelmans CT, Seynaeve C, van den Bosch LM, Dahmen G, van Geel AN, Bartels CC, Tilanus-Linthorst MM, Wagner A, Devilee P, Halley DJJ, van den Ouweland AM, Meijers-Heijboer EJ, Klijn JGM: Survival and tumor characteristics of breast-cancer patients with germline mutations of BRCAI. Lancet 1998, 35I:3|6-32|

13. Gaffney DK, Brohet RM, Lewis CM, Holden JA, Buys SS, Neuhausen SL, Steele L, Avizonis V, Stewart JR, Cannon-Albright LA: Response to radiation therapy and prognosis in breast cancer patients with BRCAI and BRCA2 mutations. Radiother Oncol 1998, 47:129-136.

14. Stoppa-Lyonnet $D$, Ansquer $Y$, Dreyfus $H$, Gautier $C$, Gauthier-Villars $M$, Bourstyn E, Clough KB, Magdelénat $H$, Pouillart $P$, Vincent-Salomon A, Fourquet A, Asselain B: Familial Invasive breast cancer: worse outcome related to BRCAI mutations. J Clin Oncol 2000 , 1 8:4053-4059.

15. Robson ME, Chappuis PO, Satagopan J, Wong N, Boyd J, Goffin JR, Hudis C, Roberge D, Norton L, Bégin LR, Offit K, Foulkes WD: A combined analysis of outcome following breast cancer: Differences in survival based on BRCAI /BRCA2 mutation status and administration of adjuvant treatment. Breast Cancer Res 2004, 6:R8-RI7.

16. Narod SA, Brunet JS, Ghadirian P, Robson M, Heimdal K, Neuhausen SL, Stoppa-Lyonnet D, Lerman C, Pasini B, de los Rios P, Weber B, Lynch $\mathrm{H}$ : Tamoxifen and risk of contralateral breast cancer in BRCAI and BRCA2 mutation carriers: a case-control study. Lancet 2000, 356:|876-188|.

17. Kuiper GG, Enmark E, Pelto-Huikko M, Nilsson S, Gustaffson JA: Cloning of a novel receptor expressed in rat prostate and ovary. Proc Natl Acad Sci USA 1996, 93:5925-5930.

18. Mosselman S, Polman J, Dijkema R: ER- $\beta$ : identification and characterisation of a novel human estrogen receptor. FEBS Lett 1996, 392:49v53.

19. Barkhem T, Carlsson B, Nilsson Y, Enmark E, Gustafsson J-Å, Nilsson $S$ : Differential response of estrogen receptor alpha and estrogen receptor $\beta$ to partial estrogen agonists/antagonists. Mol Pharmacol 1998, 54: 105-II2.

20. Speirs V: Oestrogen receptor $\beta$ in breast cancer: good, bad or still too early to tell? J Pathol 2002, 197:|43-147.

21. Eisinger F, Jacquemier J, Nogues C, Birnbaum D, Sobol H: Steroid receptors in hereditary breast carcinomas associated with BRCI or BRCA2 mutations or unknown susceptibility genes. Cancer 1999, 85:2291-2295.

22. Lynch BJ, Holden JA, Buys SS, Neuhausen SL, Gaffney DK: Pathobiologic characteristics of hereditary breast cancer. Hum Pathol 1998, 29: I | 140-II44

23. Górski B, Cybulski C, Huzarski T, Byrski T, Gronwald J, Jakubowska A, Stawicka M, Grodecka-Gazdecka S, Szwiec M, Urbański K, MituśJ, Marczyk E, Dziuba J, Wandzel P, Surdyka D, Haus O, Janiszewska $H$ Dębniak T, Tołoczko-Grabarek A, Medrek K, Masojć B, Mierzejewski M, Kowalska E, Narod SA, Lubiński J: Breast cancer predisposing alleles in Poland. Breast Cancer Res Treat 2005, 92:19-24.

24. Sørlie T, Perou CHM, Tibshirani R, Aas T, Geisler S, Johnsen H, Hastie T, Eisen MB, van de Rijn M, Jeffrey SS, Thorsen T, Quist H, Matese JC, Brown PO, Botstein D, Eystein Lønning P, Børresen-Dale $A L$ : Gene expression patterns of breast carcinomas distinguish tumor subclasses with clinical implications. PNAS 200I, 98: 10869-10874.

25. Sørlie T, Tibishirani R, Parker J, Hastie T, Marron JS, Nobel A, Deng S, Johnsen $H$, Pesich R, Geisler S, Demeter J, Perou CM, Lonning PE, Brown PO, Borresen-Dale A-L, Botstein D: Repeated observation of breast tumor subtypes in independent gene expression data sets. PNAS 2003, 100:8418-8423.

26. Foulkes WD, Stefansson IM, Chappuis PO, Bégin LR, Goffin JR, Wong N, Trudel M, Akslen LA: Germline BRCAI mutations and a basal epithelial phenotype in breast cancer. I Natl Cancer Inst 2003, 95: I482-I485.

27. van der Groep P, Bouter A, van der Zanden R, Menko FH, Buerger $H$, Verheijen RHM, van der Wall E, van Diest PJ: RE: Germline $B R C A I$ mutations and a basal epithelial phenotype in breast cancer. I Nat Cancer Inst 2004, 96:7 I2.

28. Faulkes WD, Brunet JS, Stefansson IM, Straume O, Chappuis PO, Bégin LR, Hamel N, Goffin JR, Wong N, Trudel M, Kapusta L, Porter $P$, Akslen LA: The prognostic implication of basal-like (cycline E high/p27 low/p53+ glomeruloid-microvascular-proliferation +) phenotype of BRCA I-related breast cancer. Cancer Res 2004, 64:830-835.

29. Omoto Y, Inoue S, Ogawa S, Toyama T, Yamashita H, Muramatsu M, Kobayashi S, Iwase $\mathrm{H}$ : Clinical value of the wild-type estrogen 
receptor beta expression in breast cancer. Cancer Lett 200I, 163:207-212.

30. Hopp T, Weiss H, Parra I, Cui Y, Osborne, Fuqua S: Low levels of estrogen receptor beta protein predict resistance to tamoxifen therapy in breast cancer. Clin Cancer Res 2004, 10:7490-7499.

31. Esslimani-Sahla M, Simony-Lafontaine J, Kramar A, Lavaill R, Mollevi C, Warner M, Gustafsson J-A, Rochefort H: Estrogen receptor beta (ERbeta) level but not its ERbetacx variant helps to predict tamoxifen resistance in breast cancer. Clin Cancer Res 2004, 10:5769-5776.

32. O'Neill P, Davies M, Shaaban A, Innes H, Torevell A, Sibson D, Foster C: Wild-type oestrogen receptor beta (ERbeta I) mRNA and protein expression in Tamoxifen-treated post-menopausal breast cancers. Br J Cancer 2004, 9 I: I694- I 702.

33. Murphy LC, Watson PH: Is oestrogen receptor- $\beta$ predictor of endocrine therapy responsiveness in human breast cancer. Endocr Relat Cancer 2006, 13:327-334.

34. de la Hoya M, Osario A, Godino J, Sullerio S, Tosar A, Perez-Segura P, Fernandez C, Rodríguez R, Díaz-Rubio E, Benítez J, Devilee P, Caldés T: Association between BRCAI and BRCA2 mutations and cancer phenotype in Spanish breast/ovarian cancer families: implication for genetic testing. Int J Cancer 2002, 97:466-47I.

35. Adem C, Reynolds C, Soderberg CL, Slezak JM, McDonnell SK, Sebo T], Schaid DJ, Myers JL, Sellers TA, Hartmann LC, Jenkins RB: Pathologic characteristics of breast parenchyma in patients with hereditary breast carcinoma, including BRCAI and BRCA2 mutation carriers. Cancer 2003, 97: I-II.

36. Rosen EM, Fan S, Isaacs C: BRCAI in hormonal carcinogenesis: basic and clinical research. Endocr Relat Cancer 2005, I 2:533-548.

37. Daidone MG, Veneroni S, Capelletti V, Radice P, Pierotti MA, Younes M: Estrogen receptor-beta expression in hereditary breast cancer. J Clin Oncol 2002, 20:3752-3753.

38. Gruvberger-Saal SK, Bendahl PO, Saal LH, Laakso M, Hegardt C, Eden P, Peterson C, Malmstro P, Isola J, Borg A, Ferno M: Estrogen receptor $\beta$ expression is associated with tamoxifen response in ER $\alpha$-negative breast carcinoma. Clin Cancer Res 2007, 13:1987-1994.

\section{Pre-publication history}

The pre-publication history for this paper can be accessed here:

http://www.biomedcentral.com/1471-2407/8/100/pre pub

Publish with Bio Med Central and every scientist can read your work free of charge

"BioMed Central will be the most significant development for disseminating the results of biomedical research in our lifetime. "

Sir Paul Nurse, Cancer Research UK

Your research papers will be:

- available free of charge to the entire biomedical community

- peer reviewed and published immediately upon acceptance

- cited in PubMed and archived on PubMed Central

- yours - you keep the copyright
BioMedcentral 